\title{
The dynamics of poverty, educational attainment, and the children of the disadvantaged entering medical school [Letter]
}

This article was published in the following Dove Press journal:

Advances in Medical Education and Practice

\section{Sophia von Widekind}

Faculty of Medicine, Imperial College London, London, UK
Correspondence: Sophia von Widekind Faculty of Medicine, Imperial College London, Charing Cross Hospital, Margravine Road, Hammersmith, London W6 8RP, UK

Email scv14@ic.ac.uk

\section{Dear editor}

I read with great interest the article by Baugh et al regarding socioeconomic inequalities in medical school admissions in the US and the UK. The authors explored the dynamics of poverty, including the interplay between race and socioeconomic status, barriers to intergenerational socioeconomic mobility and subsequent impact on educational attainment. I was particularly disappointed to learn that in the UK, students in the highest social stratum are 30 times more likely to receive admission to medical school than their peers in the lowest. ${ }^{1}$

It is well documented that low socioeconomic background is a barrier to accessing higher education, particularly at prestigious institutions. One UK study found that university applicants from lower-class backgrounds, state-funded schools and ethnic minority groups were less likely to apply and receive offers of admission to Russell Group universities, despite equivalent qualifications. ${ }^{2}$

Moreover, medicine in particular remains "particularly skewed toward more socioeconomically advantaged entrants". ${ }^{3}$ Unlike in the US, medicine applicants in the UK do not require an undergraduate degree. However, entry requirements include high grades at "A Level", special admission tests, a polished CV and strong performance at interview.

Attending a school experienced in supporting students through this competitive application process is undoubtedly advantageous and may outweigh the individual student's ability to attain excellent academic grades. In the UK, these might include private schools, but high house-prices in catchment areas for high-achieving state schools may also contribute to the socioeconomic divide.

Furthermore, medicine is a highly inheritable degree. ${ }^{4}$ Reasons may include but not be limited to nepotism and increased exposure to the career from a young age. Nevertheless, this phenomenon may contribute to socioeconomic inequalities within medical school admissions.

This article discusses the benefits of diversifying socioeconomic status of medical school entrants. These include the potential to alleviate health disparities, as students from underserved areas are more likely to practice in those areas once they have qualified.

A recent study demonstrated that medical students from state schools may outperform their private school peers. ${ }^{5}$ This may suggest that applicants from disadvantaged backgrounds need to work harder to attain their place at medical school and reap the 
benefit of that work ethic during their studies. Consequently, another benefit of diversifying the socioeconomic status of medical school entrants may be that those individuals go on to become better medical students and doctors.

"Resilience" is considered a highly desirable characteristic in future doctors. However, the current medical school admission system in the UK does not appear to sufficiently value the resilience demonstrated by candidates from lower socioeconomic backgrounds in matching the achievements of their more advantaged peers.

In conclusion, this article highlights an important issue in medical school admissions across the UK and worldwide. In the context of concerns in the UK that National Health Service workforce demands will not be met by current medical student numbers, it is counterintuitive that "latent capacity is being left untapped". 2 Shifting the socioeconomic imbalance will require multidisciplinary initiatives from national and local government, schools and universities alike.

\section{Disclosure}

The author reports no conflicts of interest in this communication.

\section{References}

1. Baugh AD, Vanderbilt AA, Baugh RF. The dynamics of poverty, educational attainment, and the children of the disadvantaged entering medical school. Adv Med Educ Pract. 2019;10:667-676. doi:10.2147/ AMEP

2. Boliver V. How fair is access to more prestigious UK universities? $\mathrm{Br}$ J Sociol. 2013;64(2):344-364. doi:10.1111/1468-4446.12021

3. House of Commons Library. Medical school places in England from September 2018. 2017. Available from: https://researchbriefings.parlia ment.uk/ResearchBriefing/Summary/CBP-7914\#fullreport. Accessed August 20, 2019.

4. Lentz BF, Laband DN. Why so many children of doctors become doctors: nepotism vs. human capital transfers. J Hum Resour. 1989;24(3):396-413. doi:10.2307/145820

5. Kumwenda B, Cleland JA, Walker K, Lee AJ, Greatrix R. The relationship between school type and academic performance at medical school: a national, multi-cohort study. BMJ Open. 2017;7:e016291. doi:10.1136/bmjopen-2017-016291

\begin{abstract}
Dove Medical Press encourages responsible, free and frank academic debate. The content of the Advances in Medical Education and Practice 'letters to the editor' section does not necessarily represent the views of Dove Medical Press, its officers, agents, employees, related entities or the Advances in Medical Education and Practice editors. While all reasonable steps have been taken to confirm the content of each letter, Dove Medical Press accepts no liability in respect of the content of any letter, nor is it responsible for the content and accuracy of any letter to the editor.
\end{abstract}

\section{Publish your work in this journal}

Advances in Medical Education and Practice is an international, peerreviewed, open access journal that aims to present and publish research on Medical Education covering medical, dental, nursing and allied health care professional education. The journal covers undergraduate education, postgraduate training and continuing medical education including emerging trends and innovative models linking education, research, and health care services. The manuscript management system is completely online and includes a very quick and fair peer-review system. Visit http://www.dovepress.com/testimonials.php to read real quotes from published authors. 